\author{
BULETINUL INSTITUTULUI POLITEHNIC DIN IAŞI \\ Publicat de \\ Universitatea Tehnică „Gheorghe Asachi” din Iaşi \\ Volumul 67 (71), Numărul 1, 2021 \\ Secţia \\ ELECTROTEHNICĂ. ENERGETICĂ. ELECTRONICĂ \\ DOI:10.2478/bipie-2021-0005

\section{sciendo}

\title{
NONINTRUSIVE ELECTRICAL LOADS PATTERN DETERMINATION
}

BY

\section{MARIAN BOGDAN MICU*, MARICEL ADAM and MIHAI ANDRUSCĂ}

“Gheorghe Asachi” Technical University of Iaşi, Faculty of Electrical Engineering

Received: September 14, 2021

Accepted for publication: October 6, 2021

Abstract. The paper presents a possibility to determine the electrical patterns for the electrical loads through nonintrusive monitoring of their operating regimes.

The electrical patterns are determined on the basis of the electrical parameters acquired for each load from the electrical network analysed. The determination of the electrical patterns is useful for the management of electrical energy consumption.

The easiness of the nonintrusive monitoring technique is determined by the possibility of acquiring the electrical parameters from a single measurement point from the electrical network. From the electrical parameters acquired can be obtained information for electrical loads consumption recognition and their operating regimes, for certain time intervals, and it can be established the technical condition for each load.

Keywords: nonintrusive monitoring; electrical pattern; load.

*Corresponding author; e-mail: marianbogdan.micu@yahoo.com

(C) 2021 Marian Bogdan Micu et al.

This is an open access article licensed under the Creative Commons Attribution-NonCommercialNoDerivatives 4.0 International License (CC BY-NC-ND 4.0). 


\section{Introduction}

The dynamics of the development of the electrical system imply requirements to ensure a high level of monitoring efficiency for the functioning regimes for electrical equipment.

The internal services of the power substations represent a set of electrical equipment (asynchronous motors, converters, relays, heating resistors, lighting installations, etc.) powered in alternating and continuous current which ensure proper functioning of the power substation (Micu, 2016; Micu, 2020).

For the monitoring of the electrical loads from the internal services it can be used nonintrusive monitoring based on the electrical patterns of the loads (Micu, 2019a, b).

The parameters that define the electrical pattern are: applied voltage and the absorbed current, harmonic components extracted from the alternating current signals, the phase shift between voltage and current, the power level and the energizing intervals for each load (Micu, 2020; Temneanu, 2012).

For the electrical installation analyzed, the determination of the electrical pattern of the loads starts from the acquisition of the current and voltage evolution for certain time intervals, on the basis of which is determined the power level, the harmonic components and the phase shift. Therefore, the loads are classified into different categories (inductive, inductive-resistive, or resistive).

In order to establish the profile for each load, the paper includes the simulation in the EMTP - Electromagnetic Transient Program, of these loads and the correlation of the information extracted from the program with the experimental results.

The electrical installation utilized for the experiment contains a heating resistor and a synchronous motor used in the internal services circuits. These loads are powered in alternating current. The electrical data acquisition is realized with the MavoWATT energy analyzer.

The information regarding the applied voltage, respectively the absorbed current is obtained using voltage and current transducers.

With the energy analyzer it was determined: the instantaneous values for current and voltage; active and apparent powers; the phase shift between voltages and currents; currents harmonics; connecting and disconnecting time intervals.

The numerical results obtained in the simulation were compared with the experimental results in order to validate the loads models used in the simulation. 


\section{Mathematical Model}

The mathematical model presumes the determination of the phase shift and the harmonic components. relation:

A sinusoidal signal can be described by the following mathematical

$$
X(t)=X_{a} \sin (\omega t+\varphi)
$$

where: $X_{a}$ represents the signal amplitude, $\omega=2 \pi f$ represents the pulsation and $\varphi$ represents the phase shift of the sinusoidal signal from the origin (Micu, 2020).

The sinusoidal signal described in the relation (1) can be represented by a vector that rotates counter clockwise with a certain amplitude, frequency and with a particular phase shift from the origin (Micu, 2020; Nanda, 2016; Mondal, 2014).

In Fig. 1 is represented the evolution of the instantaneous value for a sinusoidal signal as angular position on the trigonometric circle.

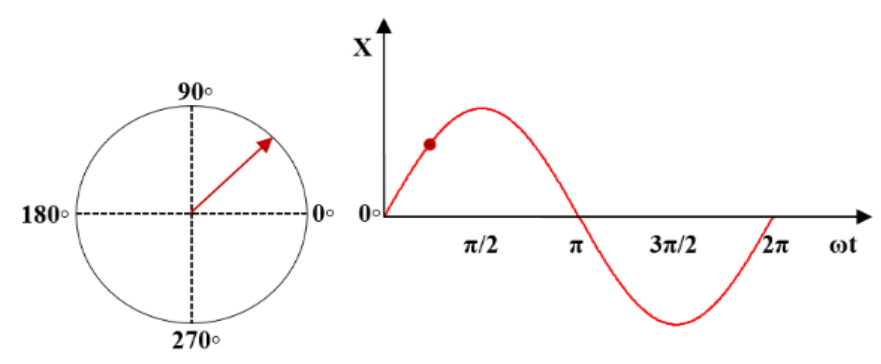

Fig. 1 - Phasor representation of the instantaneous value of a sinusoidal signal.

The amplitude of the sinusoidal signal with the pulsation $\omega$ is described in the relation $X_{a}=X_{e f} \sqrt{2}$, where $X_{e f}$ represents the effective value of the sinusoidal signal.

In the electrical systems, more often, the evolution of the electrical parameters is non-sinusoidal, the sinusoidal signal represents the ideal case.

A non-sinusoidal signal, can be decomposed, according to the Fourier theorem, into a series of sinusoidal signals of frequencies integer multiple of the fundamental frequency described in the following relation (Adam et al., 2004; Baraboi et al., 2007; Varvara, 2007; Gursoy, 2009).

$$
X(t)=X_{0}+\sum_{k=1}^{\infty} X_{k m} \sin \left(k \omega t+\gamma_{k}\right)
$$


where $X_{0}$ represents the continuous component, $X_{k m}$ represents the amplitude of the $k$ order harmonic, $\gamma_{k}$ is the initial phase of the $k$ order harmonic, for $k=1$ it is obtained the fundamental signal.

\section{Case Study}

The paper presents a possibility of determination the electrical patterns for the electrical loads from the internal services of the power substation, by nonintrusive acquisition of the electrical parameters for a motor with a power of $0.5 \mathrm{~kW}$ and a heating resistor with a power of $700 \mathrm{~W}$.

In the paper were validated the simulation data performed in EMTP tool for an electrical installation within the internal services of the power substation which includes one motor and one heating resistor.

The loads are powered in alternating current, at network voltage, with the frequency of $50 \mathrm{~Hz}$, according to the simplified electrical diagram presented in Fig. 2.

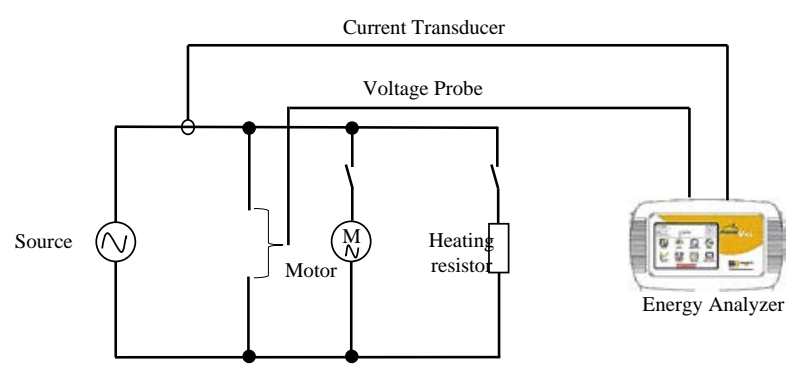

Fig. 2 - Simplified electrical diagram.

To data acquire from the electrical circuit the diagram uses the energy analyzer which reads the information regarding the absorbed current and the applied voltage for each load. The electrical data were acquired using voltage and current transducers. Therefore, by using the energy analyzer were determined the instantaneous and effective values for the voltage and current signals, apparent power, the amplitude of the harmonic components and the phase shift - the relation between the voltage and current signal reported to the fundamental frequency $(50 \mathrm{~Hz})$, according to the Fourier theorem.

The profile for each load is identified by the phase shift determination, and the loads are classified into the following categories: inductive, inductiveresistive or resistive.

From the evolution of the power absorbed by each load are extracted information regarding the operating regimes of the loads as: starting transient regime or the normal functioning regime of the motor, connection or disconnection of some loads, etc. 
The data obtained from the simulation are compared with the data obtained from the experimental setup in order to determine the deviations related to each load.

In Fig. 3 is represented the apparent power $\mathrm{S}$ in VA for the motor.
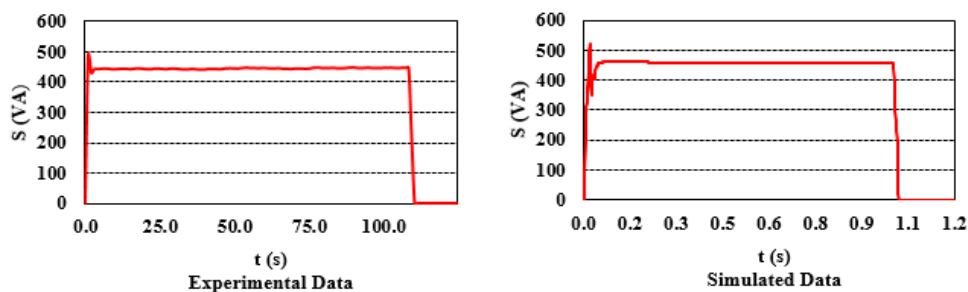

Fig. 3 - Power absorbed by the motor.

The apparent power determined from the experiment, $\mathrm{S}=457 \mathrm{VA}$, and the apparent power determined from the simulation is $\mathrm{S}=462 \mathrm{VA}$.

The evolution of the current signal for the starting transient regime for the motor is presented in Fig. 4.
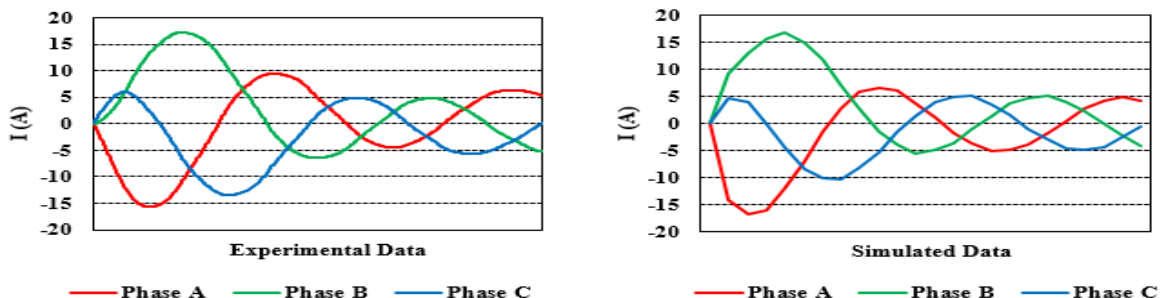

Fig. 4 - Starting transient regime for the motor.

The maximum instantaneous value for the absorbed current from the starting regime, measured from the experiment, and from the simulation, for a single phase is $\mathrm{I}=16 \mathrm{~A}$.

In Fig. 5 are presented the evolutions of the current and voltage signals determined for the normal functioning regime for the motor, and the current and voltage phasors.
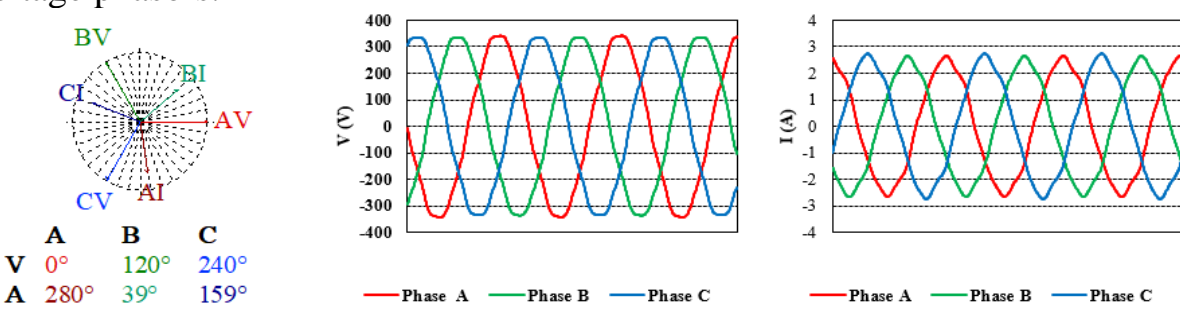

Fig. 5 - Evolution of current and voltage signals and phasor diagram from the experimental setup. 
The motor absorbs a current with the effective value of $\mathrm{I}=1.89 \mathrm{~A}$, and the effective value of the applied voltage is $242 \mathrm{~V}$.

The voltage signal is out of phase before the current signal with 81 electrical degrees.

In Fig. 6 is presented the evolution of the current and voltage for each phase, determined from the simulation for the normal functioning regime for the motor.
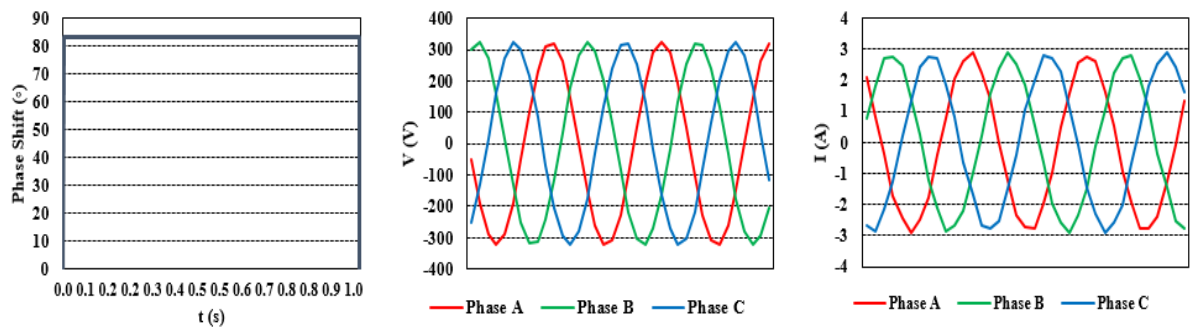

Fig. 6 - Evolution of the voltage and current signals and the phase shift determined from simulation.

The phase shift between the applied voltage and the absorbed current, determined from the simulation is 83 electrical degrees.

From the phasor diagram of voltage and current phasors it can be observed the inductive - resistive character of the motor.

The harmonic components evolution, determined for a single phase for the motor is presented in Fig. 7.

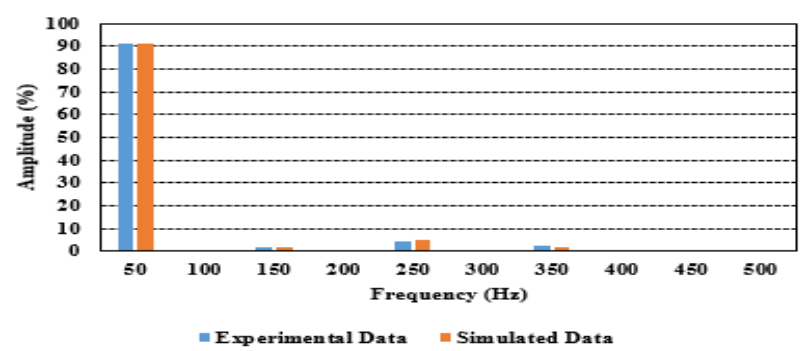

Fig. 7 - The evolution of the harmonic components for the motor.

From the measurements made, it can be observed that the predominant harmonic is $50 \mathrm{~Hz}$, approximately $90 \%$ due to the nonlinear character of the magnetic circuit and also 90\% for the harmonic analysis determined from the simulation.

In Fig. 8 are presented the evolutions of the apparent powers for the heating resistor, determined with the energy analyzer respectively from simulation. 

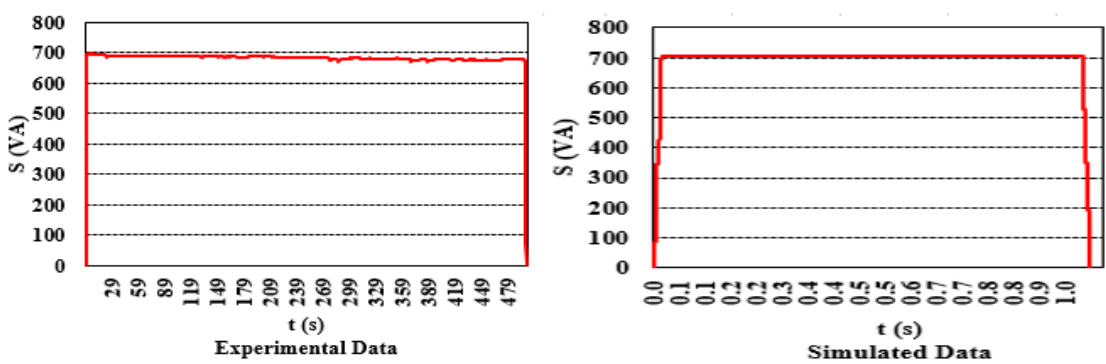

Fig. 8 - Apparent power for the resistor.

The resistor absorbs an apparent power $\mathrm{S}=700 \mathrm{VA}$. Form the simulation made, the value of the power determined is $703 \mathrm{VA}$. The apparent power was measured for an interval of $\Delta \mathrm{t}=500 \mathrm{~s}$ and it can be observed a decrease of the value due to the modification of the resistance as a function of temperature. In the case of the simulation the power remains constant over time due to the linearity of the model.

In Fig. 9 is presented the evolution of the applied voltage and the absorbed current for the resistor, determined experimental and respectively from simulation.
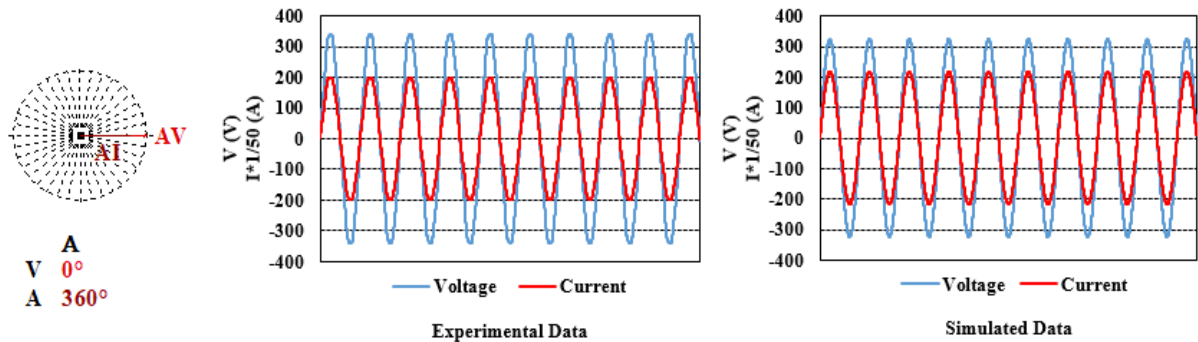

Fig. 9 - Evolution of the electrical parameters and the phasor diagram for the resistor.

The voltage and current signals are in phase, the phase shift is null, the resistor has resistive character.

The effective values for the absorbed current respectively for the applied voltage, determined from the experiment are: $\mathrm{I}=2.87 \mathrm{~A}$ and $\mathrm{V}=244 \mathrm{~V}$.

The effective values for the electrical parameters, voltage and current, determined from the simulation are: $\mathrm{I}=3.07 \mathrm{~A}$ and $\mathrm{U}=229 \mathrm{~V}$.

In Fig. 10 is represented the evolution of the harmonic components determined from the experiment respectively from the simulation, for the resistor. 


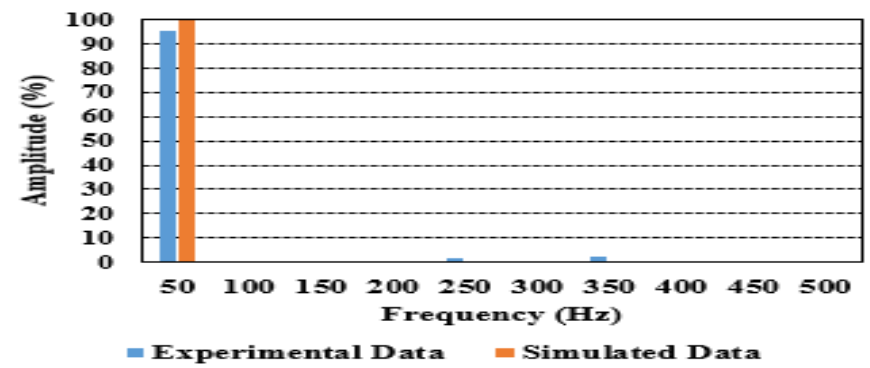

Fig. 10 - Evolution of the harmonic components for the resistor.

The predominant harmonic component for the resistor is $50 \mathrm{~Hz}$, approximately $95 \%$ determined from the experiment respectively $99 \%$ determined from simulation.

In Table 1 are presented the values of the electrical parameters for the loads.

Table 1

Electrical Parameters of the Loads

\begin{tabular}{|c|c|c|c|c|c|c|c|c||}
\hline \hline & \multicolumn{4}{|c|}{ Experimental } & \multicolumn{4}{c|}{ Simulation } \\
\hline \hline Load & $\begin{array}{c}S \\
(\mathrm{VA})\end{array}$ & $\begin{array}{c}I_{R M S} \\
(\mathrm{~A})\end{array}$ & $\begin{array}{c}U_{R M S} \\
(\mathrm{~V})\end{array}$ & $\begin{array}{c}\text { Phase } \\
\text { Shift } \\
\left({ }^{\circ}\right)\end{array}$ & $\begin{array}{c}S \\
(\mathrm{VA})\end{array}$ & $\begin{array}{c}I_{R M S} \\
(\mathrm{~A})\end{array}$ & $\begin{array}{c}U_{R M S} \\
(\mathrm{~V})\end{array}$ & $\begin{array}{c}\text { Phase } \\
\text { Shift } \\
\left({ }^{\circ}\right)\end{array}$ \\
\hline \hline Motor & 457 & 1.89 & 242 & 81 & 462 & 2.02 & 229 & 83 \\
\hline Resistor & 700 & 2.87 & 244 & 0 & 703 & 3.07 & 229 & 0 \\
\hline \hline
\end{tabular}

The deviations from the values determined from the simulation compared with those determined from the experiment indicate the need to improve the models in the simulation.

The deviations are determined by the nonlinear characteristic of the magnetic circuit of the motor, and by the modification of the resistance as a function of temperature in the case of the resistor.

\section{Conclusions}

The paper presents a nonintrusive method for the determination of the electrical patterns for the loads from the internal services of the power substation.

The electrical pattern consists in the determination of the phase shift between the absorbed current and the applied voltage, harmonic components which identify the distortion variations from the electrical installation analysed, power consumed and the connection and disconnection time intervals of the loads. 
By comparison the data obtained from simulation with the data obtained from experimental data, are validated the loads models used in numerical simulation.

\section{REFERENCES}

Adam M., Baraboi A., Electronică de putere. Invertoare statice, Editura Venus, Iași, 2004.

Baraboi A., Adam M., Popa S., Pancu C., Compatibilitate Electromagnetică, Editura PIM, Iași, 2007.

Gursoy E., Niebur D., Harmonic Load Identification Using Complex Independent Component Analysis, IEEE Transactions on Power Delivery, Vol. 24, No. 1, January 2009.

Micu M., Adam M., Andrusca M., Deac C., Aspects Regarding the Loads Patterns Determination from the Internal Services of the Power Substations, International Conference on electrical Power Engineering (EPE), Iași 2020.

Micu M.B., Adam M., Andrusca M., Deac C., Possibilities of Monitoring, Commands and Control of the Circuit Breakers, International Conference on Electromechanical and Energy Systems (SIELMEN), pp. 1-4, October 2019.

Micu M.B., Adam M., Andrusca M., Boghiu B., Aspects Regarding the Nonintrusive Load Monitoring and Electrical Equipment Diagnosis from Power Substations, 9th International Conference and Exposition on Electrical and Power Engineering (EPE), pp. 1-4, October 2016.

Micu M.B., Adam M., Andrusca M., Deac C., Aspects Regarding the Electromagnetic Pattern for the Operating Mechanism of a Medium Voltage Circuit Breaker, 8th International Conference on Modern Power Systems (MPS), pp. 1-4, July 2019.

Mondal S., Murthy Ch., Roy D.S., Mohanta D.K., Simulation of Phasor Measurement Unit (PMU) Using Labview, IEEE Transactions on Power Delivery, May, 2014.

Nanda P., Panigralli C.K., Dasgupta A., Phasor Estimation on Recent Advancement in Air Conditioning and Refrigeration, RAAR 2016, 10-12 November 2016, Bhubaneswar, India.

Temneanu M., Smart Metering Device with Incorporated Load Identification Features, Sigmet PCCA 30/2012.

Varvara V., Teoria Circuitelor Electrice, Editura Tehnică, Știinţifică şi DidacticăCermi, Iași, 2007, pp. 507-510.

\section{DETERMNAREA NEINVAZIVĂ A AMPRENTELOR ELECTRICE ALE CONSUMATORILOR}

(Rezumat)

Lucrarea prezintă o posibilitate de determinare a amprentelor electrice ale consumatorilor prin monitorizarea neintrusivă a regimurilor de funcționare ale acestora. 
Amprentele electrice sunt determinate pe baza parametrilor electrici achiziționați pentru fiecare consumator din schema electrică analizată. Determinarea amprentelor electrice este utilă pentru managementul consumului de energie electrică. Ușurința monitorizării neintrusive este determinată de posibilitatea achiziției parametrilor electrici dintr-un singur punct de măsură din instalația electrică. Prin intermediul parametrilor electrici achiziționați se pot obține informații privind recunoașterea consumatorilor și regimul de funcționare al acestora, pe anumite intervale de timp, şi se poate stabili starea tehnică a lor. 